\title{
Differential expression of oestrogen receptor and oestrogen inducible genes in gastric mucosa and
} cancer

\author{
S Singh, R Poulsom, N A Wright, M C Sheppard, M J S Langman
}

\begin{abstract}
Background-Evidence exists for a role for oestrogen in gastric cancer. The incidence of gastric cancer is much higher in men than in woman, and a similar sex difference is also seen in a rat experimental model of gastric cancer.

Aims-Evidence for a functional oestrogen receptor in normal gastric mucosa and cancer has been sought.

Methods-Oestrogen receptor and the oestrogen inducible genes pS2 and ERD5 were sought by northern blot analysis and in situ hybridisation and immunohistochemistry. Oestrogen receptor protein was studied by enzyme immunoassay. Results-mRNA for oestrogen receptor was detected in cancer and normal gastric mucosa. Enzyme immunoassay for oestrogen receptor showed a mean of 1.8 fmol/mg protein in cancer and $13.7 \mathrm{fmol}$ mg in paired normal mucosa. The oestrogen inducible genes pS2 and ERD5 were also detected in both cancer and normal mucosa, with expression localised to epithelium. Expression of pS2 was lower in cancer compared with normal mucosa, whereas ERD5 expression was higher in cancer.
\end{abstract}

Conclusions-Significant amounts of oestrogen receptor were expressed in gastric mucosa with a lower amount in cancer. Oestrogen inducible genes were also expressed differentially but were not found to correlate closely with oestrogen receptor. Oestrogen receptor functionality remains to be demonstrated in the stomach.

(Gut 1997; 40: 516-520)

Keywords: stomach neoplasms, sex hormones.

The aetiology of gastric cancer is largely unknown, but is likely to be multifactorial. A consistent sex difference is seen in areas of high and low incidence of gastric cancer; males have twice the incidence of females. ${ }^{1}$ A male preponderance is also seen in a rat experimental model of gastric cancer; MNNG (N-methyl$\mathrm{N}$-nitro-N-nitosoguanidine) induced gastric cancers are more than twice as common in male rats than in female rats. ${ }^{2}$ Furthermore, an early menopause predisposes women to gastric cancer. $^{3}$ It is possible, therefore, that sex steroid hormones have a role in gastric cancer with oestrogen having a protective role or androgens increasing the risk.

If oestrogen is to have a role in gastric cancer, then functional oestrogen receptor should be present in gastric mucosa. Previous studies have found evidence of oestrogen receptor in normal mucosa and cancer, ${ }^{4}{ }^{5}$ but the localisation and functionality of the receptor remains unclear. We have looked for oestrogen receptor expression in normal and cancerous gastric mucosa using northern blot analysis, in situ hybridisation, and immunohistochemistry. To provide evidence of oestrogen receptor function we have looked for the expression of the oestrogen inducible proteins $\mathrm{pS} 2$ and $E R D 5^{67}$ because the expression of these in breast cancer correlates with expression of functional oestrogen receptor. ${ }^{89}$

\section{Methods}

Tissue samples were collected into liquid nitrogen within 20 minutes of resection of surgical specimens. Non-necrotic cancer was identified and removed, and a sample of normal mucosa was dissected from the muscularis propria about $5 \mathrm{~cm}$ from the cancer. Tissue was also collected from surgical resections for non-gastric disease. Tissue samples were stored at $-70^{\circ} \mathrm{C}$.

\section{NORTHERN BLOT ANALYSIS}

Total RNA was extracted by the single step guanidinium isothiocyanate method. ${ }^{10}$ Integrity of the RNA was assessed by the visualisation of distinct ribosomal $28 \mathrm{~S}$ and $18 \mathrm{~S}$ bands on a $1 \%$ agarose gel stained with ethidium bromide. Northern blot analysis was performed by electrophoresis of about $30 \mu \mathrm{g}$ of total RNA in a $1 \%$ agarose gel containing $15 \%$ formaldehyde in $20 \mathrm{mM}$ morpholinopropanesulphonic acid (MOPS buffer). RNA was transferred for three hours in $0.05 \mathrm{M}$ sodium hydroxide to Hybond $\mathrm{N}+$ nylon membranes (Amersham International, Buckinghamshire, UK).

CDNA PROBES AND MEMBRANE HYBRIDISATION The partial cDNA clone pOR3 of the human oestrogen receptor ${ }^{11}$ was obtained from the Medical Research Council UK DNA Probe Bank, Harrow, England. Probes for cDNA were also used for ERD5, ${ }^{12}$ and $\mathrm{pS} 2{ }^{6}$ Probes were validated by multiple restriction enzyme 
digestions and by sequencing. To determine total RNA loading, northern blots were probed with a cDNA coding for the rat $18 \mathrm{~S}$ ribosomal RNA. ${ }^{13}$

Probes were radiolabelled with $\alpha\left[{ }^{32} \mathrm{P}\right] \mathrm{dCTP}$ (deoxycytidine triphosphate, $3000 \mathrm{Ci} / \mathrm{mmol}$ ) using the random primer extension technique to an activity of $10^{9} \mathrm{cpm} / \mu \mathrm{g}$. Membranes were hybridised overnight in a buffer comprising $0.77 \mathrm{M}$ sodium phosphate, $5 \mathrm{mM}$ EDTA, $7 \%$ sodium dodecyl sulphate (SDS), and 100 $\mu \mathrm{g} / \mathrm{ml}$ denatured salmon sperm DNA at $65^{\circ} \mathrm{C}$ in a rotating oven (Hybaid, Middlesex, UK). Membranes were washed in $1 \times$ SSC $(0.015 \mathrm{M}$ sodium citrate, $0.15 \mathrm{M}$ sodium chloride), and $1 \%$ SDS at $65^{\circ} \mathrm{C}$ for one hour, followed by $0.1 \times$ SSC and $0.1 \%$ SDS at $65^{\circ} \mathrm{C}$ for 15 minutes. The membranes were autoradiographed at $-70^{\circ} \mathrm{C}$ with intensifying screens. Membranes were then stripped at $70^{\circ} \mathrm{C}$ in $0.5 \%$ SDS and reprobed after all activity had been removed as demonstrated by autoradiography. Autoradiograms were analysed by laser densitometry (LKB Ultroscan, Pharmacia Biosystems, Milton Keynes, UK).

Total RNA was also analysed from the human breast carcinoma cell line MCF-7 and human uterus to provide a positive control for oestrogen receptor and oestrogen inducible genes.

IN SITU HYBRIDISATION FOR OESTROGEN RECEPTOR AND $\mathrm{pS} 2$

In situ hybridisation for oestrogen receptor and PS2 mRNA was performed to localise tissue expression. Briefly, antisense riboprobes were transcribed with SP6 RNA polymerase (Promega Biotechnology, Southampton, UK) from the Eco-RI-Ball fragment of the oestrogen receptor subcloned into pGEM3 (Promega). The antisense probe for pS2 was made using SP6 RNA polymerase and EcoRI linearised pSP73 containing the EcoRI/BgIII fragment of the PCR clone. Probes were labelled with ${ }^{35}$ SUTP (uridine triphosphate) to a specific activity $0 \cdot 8-1 \cdot 7 \times 10^{9} \mathrm{dpm} / \mu \mathrm{g}$ RNA. Sections of formalin fixed material $(5 \mu \mathrm{m})$ were mounted on 3-aminopropyl-triethoxysilane treated glass sides, dewaxed, and hydrated in phosphate buffered saline (PBS). Sections were permeabilised with proteinase $K$, postfixed in $4 \%$ paraformaldehyde, acetylated, and incubated overnight at $55^{\circ} \mathrm{C}$ in $10-20 \mu l$ hydridisation mixture $(300 \mathrm{mM} \mathrm{NaCl}, 10 \mathrm{mM}$ $\mathrm{Na}_{2} \mathrm{HPO}_{4}, 10 \mathrm{mM}$ Tris- $\mathrm{HCl}, 5 \mathrm{mM}$ EDTA, $0.02 \%$ bovine serum albumin, $0.02 \%$ Ficoll $400,0.02 \%$ polyvinyl pyrolidone, $50 \%$ formamide, $0.5 \mathrm{mg} / \mathrm{ml}$ bovine ribosomal RNA, $10 \%$ dextran sulphate, $10 \mathrm{mM}$ dithiothreitol). Probe $\left(1-2 \times 10^{6} \mathrm{cpm}\right)$ was added to each slide. Posthybridisation washes included a ribonuclease A step and reached a final stringency of $0.5 \times S S C$ at $65^{\circ} \mathrm{C}$. Sections were dehydrated in alcohols containing $300 \mathrm{mM}$ ammonium acetate, dried, dipped in Ilford $\mathrm{K} 5$ emulsion, and exposed for three to nine weeks at $4^{\circ} \mathrm{C}$ before development of silver grains in Kodak D19. Sections were counterstained with Giemsa stain. Hybridisation with oestrogen receptor sense riboprobe transcribed with $\mathrm{T} 7$ polymerase provided a control to estimate nonspecific hybridisation. Hybridisation with a $\beta$ actin antisense riboprobe was performed to show the presence of hybridisable $\mathrm{mRNA}$ in the blocks sectioned.

OESTROGEN RECEPTOR ENZYME IMMUNOASSAY A commercially available immunoassay was used according to the manufacturer's instructions (Abbott Laboratories, Berkshire, UK). Briefly, the tissue was homogenised in a buffer comprising $10 \%$ glycerol, $10 \mathrm{mM}$ HEPES, 1.5 mM EDTA, $0.5 \mathrm{M}$ potassium chloride, and 5 $\mathrm{mM}$ sodium molybdate. The homogenate was centrifuged at $10000 \mathrm{~g}$. The tissue cytosol and oestrogen receptor standards provided were incubated with beads coated with a rat antioestrogen receptor monoclonal antibody. The beads were washed to remove unbound material. Bound oestrogen receptor was labelled by incubating with a second monoclonal antioestrogen receptor antibody conjugated with horseradish peroxidase. After washing, the beads were incubated with enzyme substrate (hydrogen peroxide and $o$-phenylenediamine$\mathrm{HCl}$ ), and the colour developed was read on a spectrophotometer set at $492 \mathrm{~nm}$. A standard curve was established and specimen values determined. Total cytosolic protein was estimated using the Bradford method (Bio-rad Laboratories, Hertfordshire, UK). ${ }^{14}$

IMMUNOHISTOCHEMISTRY FOR OESTROGEN RECEPTOR, pS2, AND ERD5

Commercially available monoclonal antibodies were used. Antibody against the human oestrogen receptor was obtained from Dako Ltd (Buckinghamshire, UK). Antibodies against pS2 and ERD5 were obtained from CIS bio International, Gif-sur-Yvette Cedex, France, and Amersham International, Buckinhamshire, UK), respectively.

Tissue was fixed in neutral buffered formalin before being embedded in paraffin wax. Sections were dewaxed and endogenous peroxidase was blocked with $0.3 \%$ hydrogen peroxide in methanol. Sections to be stained for oestrogen receptor were placed in a microwave oven for 10 minutes in $7 \mathrm{mM}$ sodium citrate, as recommended by the manufacturer. Sections were incubated with the primary antibody for 30 minutes, washed, and incubated with biotinylated rabbit antimouse antibody for 35 minutes. Sections were then washed and incubated for 30 minutes in streptavidinperoxidase. The sections were washed and incubated for two minutes in peroxidase substrate (diaminobenzidine and $0.3 \%$ hydrogen peroxide) and counterstained with haematoxylin. Control sections were processed as above omitting the primary antibody.

\section{Results}

Thirteen pairs of gastric cancer cells and normal adjacent mucosae were analysed by northern blot analysis. Three were defined as 


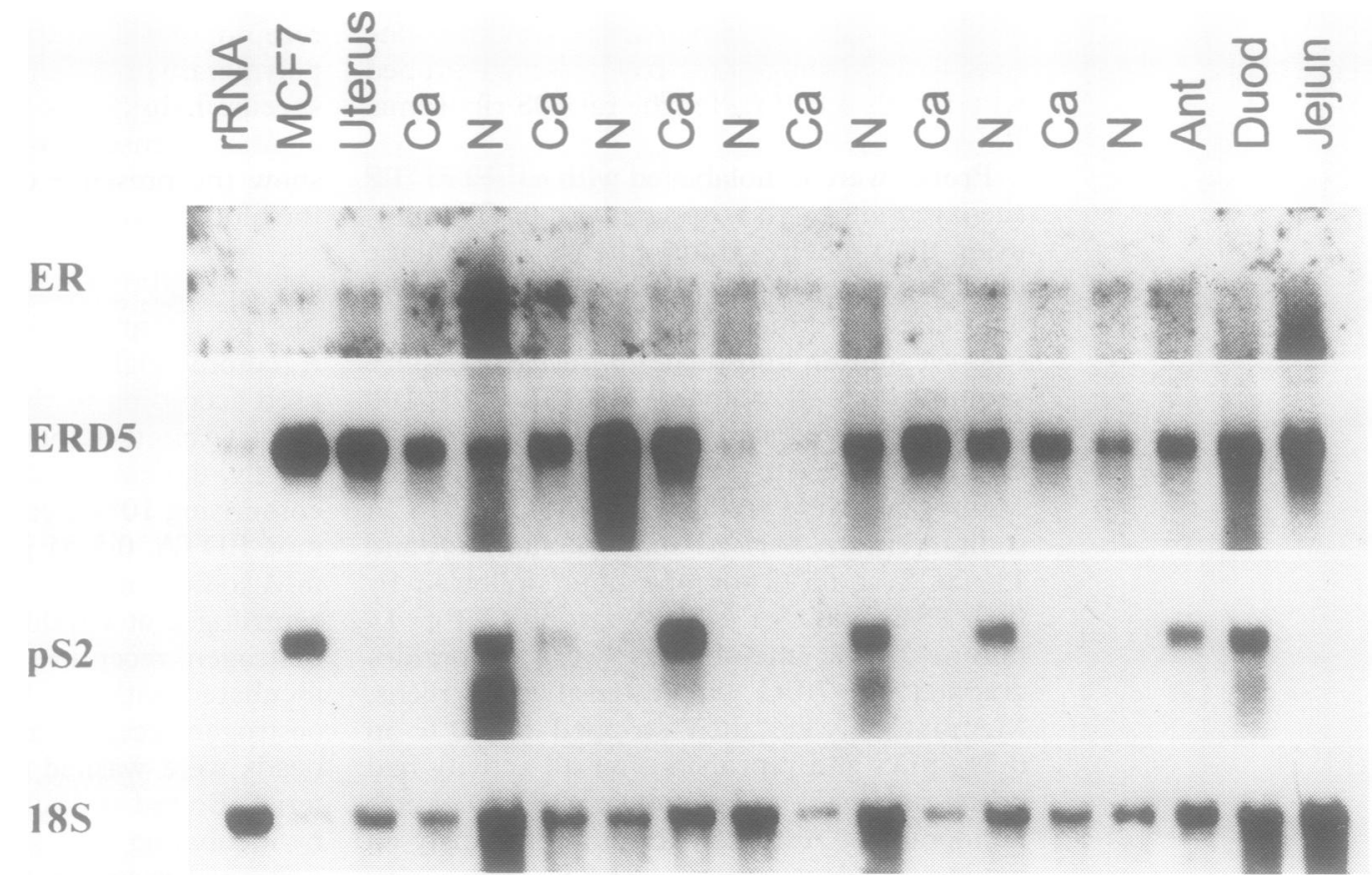

Figure 1: Expression of $m R N A$ for oestrogen receptor and oestrogen inducible genes pS2 and ERD5 in paired cancer and normal gastric mucosa $(C-N)$. Shown are autoradiographs of northern blots hybridised to $c D N A$ probes for oestrogen receptor (ER), ERD5, $p S 2$, and $18 S$ ribosomal $R N A$. Cancers were from men and women. $18 S$ ribosomal RNA indicates amount of total RNA loaded. RNA from the breast cancer cell line MCF-7, and from human uterus provide positive controls. Ant=gastric antrum; duod=duodenum; jejun=jejunum; $C a=$ cancer; $N=$ normal.

"diffuse" according to the Lauren classification, and 10 were "intestinal" in type. In addition, normal gastric mucosa and small bowel were analysed from two patients undergoing radical pancreatic surgery. The mean age of the patients was 72 (range 58 to 82 ) years. Five patients were women.

\section{OESTROGEN RECEPTOR}

Northern blot analysis identified mRNA for oestrogen receptor in all samples of gastric cancer and normal mucosa. Figure 1 shows the results in six representative cancer and normal pairs. The transcript identified is likely to be specific for oestrogen receptor as we had used stringent probe hybridisation and washing conditions, and the transcript was identical in size to that expressed by MCF-7 breast cancer cells $(6.2 \mathrm{~Kb})^{11}$ and uterus. Furthermore, no binding was seen with calf liver ribosomal RNA (negative control; lane 1, Fig 1). After correcting laser densitometry readings for uneven loading by expressing oestrogen receptor mRNA as a ratio of $18 \mathrm{~S}$ ribosomal RNA, no quantitative difference in oestrogen receptor mRNA expression was seen between cancer cells and normal gastric mucoca. Oestrogen receptor was also found in the two samples of

Mean $(n=9)$ expression of oestrogen receptor protein (SEM) (fmol/mg protein) and mRNA (SEM) for the oestrogen inducible genes, ERDS and $p S 2$, in gastric cancer and paired normal mucosa $(n=13)$ (arbitrary units)

\begin{tabular}{|c|c|c|c|}
\hline & $\begin{array}{l}\text { Oestrogen } \\
\text { receptor }\end{array}$ & ERD5 & $p S 2$ \\
\hline $\begin{array}{l}\text { Cancer } \\
\text { Normal mucosa }\end{array}$ & $\begin{array}{r}1 \cdot 8(0 \cdot 6)^{\star} \\
13 \cdot 7(4 \cdot 3)\end{array}$ & $\begin{array}{c}10 \cdot 0(4 \cdot 2)^{\star} \\
2 \cdot 7(1 \cdot 0)\end{array}$ & $\begin{array}{l}10 \cdot 0(9 \cdot 5)^{\star \star \star} \\
16.4(3.8)\end{array}$ \\
\hline
\end{tabular}

${ }^{\star} \mathrm{p}<0.05 ;{ }^{\star \star \star} \mathrm{p}<0.001$, Mann-Whitney U test $v$ normal controls. small bowel mucosa examined (Fig 1). In situ hybridisation for oestrogen receptor was unsuccessful at localising expression, although expression was identified in slides of uterus (positive control)/(data not shown).

Enzyme immunoassay for oestrogen receptor showed much lower expression in cancer compared with adjacent normal mucosa, a mean (range) of $1.8(0 \cdot 1-5 \cdot 0) \mathrm{fmol} /$ $\mathrm{mg}$ protein and $13.7(0 \cdot 6-32 \cdot 6) \mathrm{fmol} / \mathrm{mg}$ respectively (Table). This difference was significant ( $<<0.05$, Mann-Whitney U test). There was no difference in oestrogen receptor expression between men $(n=6)$ or women $(n=3)$, although the numbers studied were small. Immunohistochemistry for oestrogen receptor was not successful at localising expression, although positive staining was seen on slides of uterus (data not shown).

pS2

Northern blot analysis disclosed a major transcript identical in size to that expressed in the MCF-7 cells $(0.6 \mathrm{~Kb}){ }^{6}$ A smaller transcript of approximately $0.4 \mathrm{~Kb}$ was also seen in gastric tissues (Fig 1). The expression of the minor transcript varied in parallel with that of the major $0.6 \mathrm{~Kb}$ transcript. There was no difference in transcript size between normal mucosa and cancer. However, expression of pS2 was significantly lower in cancer (Table).

In situ hybridisation localised expression to surface epithelium in normal mucosa (Fig 2A). Expression in cancer cells was noted to be heterogeneous with adjacent signets of malignant cells having disparate expression of $\mathrm{pS} 2$ (Fig 2B). Immunohistochemistry for pS2 also localised expression to epithelium (data not shown). 


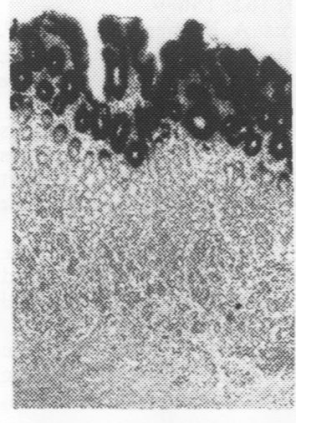

A

Figure 2: In situ hybridisation for the oestrogen inducible gene $p S 2,(A)$ in normal gastric mucosa, and $(B)$ in a moderately differentiated cancer. Expression of pS2 is in surface epithelium in normal mucosa. In cancer pS2 expression is heterogeneous.

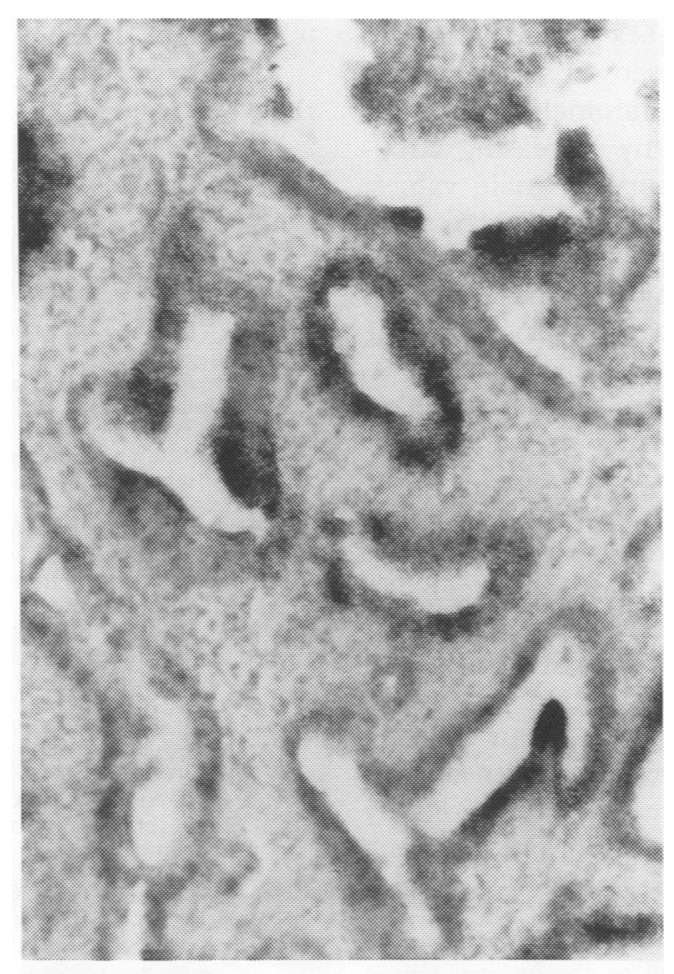

B

ERD5

Northern blot analysis identified a single transcript of approximately $1 \mathrm{~Kb}$ in gastric tissue, identical in size to that seen in MCF-7 cells and uterus (Fig 1). Expression of ERD5 was, in contrast to expression of $\mathrm{pS} 2$, higher in cancer than in normal mucosa (Table). Immunohistochemistry showed faint staining in normal and malignant epithelium (data not shown).

\section{Discussion}

We have found evidence for oestrogen receptor mRNA and protein and oestrogen inducible genes in normal gastric mucosa and cancer cells from the stomach. Although mRNA for oestrogen receptor is equally expressed in normal mucosa and cancer, oestrogen receptor protein itself is expressed in much lower amount by cancer. The oestrogen inducible genes examined, pS2 and ERD5, are also differentially expressed, with pS2 expression being lower in cancer, whereas ERD5 was expressed in higher amount in cancer.

The amount of oestrogen receptor we have detected in normal gastric mucosa is striking, a mean of $14 \mathrm{fmol} / \mathrm{mg}$, an amount greater than the $2-10 \mathrm{fmol} / \mathrm{mg}$ seen in normal breast tissue. Wu et $a l^{4}$ detected a lower amount of oestrogen receptor in normal gastric tissue, and found a similar level of oestrogen receptor in gastric cancer. One possible reason for this discrepancy is that we have used mucosa dissected from the muscularis propria, and not used whole stomach including gastric smooth muscle, which would tend to dilute down the oestrogen receptor content of gastric mucosa.

Our attempts to confirm oestrogen receptor expression in gastric epithelium by in situ hybridisation and immunohistochemistry were unsuccessful. Kojima $e t a l^{5}$ failed to detect immunostaining for oestrogen receptor in normal mucosa, although they reported positive receptor staining in a minority of cancers after very prolonged incubation with primary antibody. The absence of immunohistochemical staining for oestrogen receptor in normal gastric mucosa may simply reflect a limitation in sensitivity of the technique, and it should be noted that even breast, a classic oestrogen responsive tissue, fails to stain for oestrogen receptor during the luteal phase of the menstrual cycle. ${ }^{15}$

Expression of the oestrogen inducible genes pS2 and ERD5 in breast tissue correlates with the presence of functional oestrogen receptor. The correlation between ERD5 and oestrogen receptor is high. Thus antibody to ERD5 can immunoprecipitate ligand bound oestrogen receptor, ${ }^{16}$ ERD5 expression in linearly correlated with specific binding for oestrogen in breast tissue, ${ }^{17}$ and ERD5 status has similar clinical prognostic relevance to oestrogen receptor expression in breast cancer. ${ }^{9}$ pS2 expression is also closely related to expression of oestrogen receptor in breast tissue. Oestradiol promotes transcription of $\mathrm{pS} 2$ mRNA in breast cancer cells, ${ }^{6}$ acting via an oestrogen response element (ERE), which is present upstream of the transcription start site. ${ }^{18}$ Expression of pS2 correlates with the presence of oestrogen receptor in breast cancers, ${ }^{8}$ and is predictive of response to antioestrogen therapy. ${ }^{19}$

We have detected ERD5 and pS2 in normal gastric mucosa and cancer as previously reported. ${ }^{20} 21$ However, pS2 and ERD5 expression was not co-localised nor correlated with oestrogen receptor - for example, we have detected lower amounts of oestrogen receptor protein in gastric cancer compared with normal mucosa; however, ERD5 mRNA concentrations were higher in cancer. Thus other factors in addition to oestrogen may be important in the regulation of these genes in stomach; pS2 is also inducible by the epidermal growth factor and the proto-oncogenes c-jun and cHa-ras. ${ }^{22}$

If oestrogen receptor expression affected the behaviour of gastric cancer then anti-oestrogens might be expected to affect prognosis, and expression of oestrogen inducible genes might also predict outcome. Tamoxifen in combination with chemotherapy has been reported by some to improve survival, ${ }^{23}{ }^{24}$ but other studies have shown no effect. ${ }^{25}$ However, in the study of Harrison et $a l^{25}$ patients with cancers positive for ERD5 had a significantly lower survival when treated with tamoxifen. The same group also reported that ERD5 status of gastric cancer was an independent prognostic factor; patients with ERD5 positive cancers having a significantly shorter survival. ${ }^{26}$ The position is therefore unclear.

The antiulcer drug cimetidine has been documented to improve survival in gastric cancer. ${ }^{27}$ The mechanism is not known, but may be endocrine in action as the drug is recognised to have oestrogenic or antiandrogenic side effects, such as gynaecomastia and impotence. 
Other evidence relating sex steroid actions to gastric physiology includes lower serum gastrin concentrations in female animals than male animals, ${ }^{28}$ with ovariectomy increasing circulating gastrin concentrations to male values. When treated with oestradiol, ovariectomised rats develop lower serum gastrin concentrations. ${ }^{29}$ It is noteworthy that the oestrogen stilboestrol has been used with benefit for the treatment of duodenal ulcer in humans. ${ }^{30}$

We have detected significant amounts of oestrogen receptor in normal gastric mucosa with lower amounts in cancer cells. This is consistent with oestrogen having a protective action and may contribute to the sex difference seen in the incidence of gastric cancer. To determine evidence of oestrogen receptor functionality we looked for the oestrogen inducible genes pS2 and ERD5 in gastric tissue. Both genes were detected, but we were unable to show close correlation with oestrogen receptor. Oestrogen receptor functionality remains to be demonstrated in stomach tissue.

This work was supported by the Medical Research Council with a training fellowship (to SS) and by the Imperial Cancer Research Fund.

1 Perkin DM, Muir CS, Whelon SL, et al. Cancer incidence in five continents. Lyon: International Agency for Research on Cancer, 1992; 6: 1-1033. (IARC scientific publ No 120.)

2 Furukawa $H$, Iwanaga $T$, Koyama $H$, Taniguchi $H$. Effect of sex hormones on carcinogenesis in the stomachs of rats. Cancer Res 1982; 42: 5181-2.

3 Palli D, Cipriani F, Decarli A, Galli M, Saieva C Fraumeni JF Jr, et al. Reproductive history and gastric
cancer among post-menopausal women. Int 7 Cancer cancer among

4 Wu CW, Chang HM, Kao HL, Lui WY, Peng FK, Chi CW The nontransformed progesterone and estrogen receptor in gastric cancer. Gastroenterology 1992; 102: 1639-46.

5 Kojima O, Takahashi T, Kawakami S, Uehara Y, Matsui M Localization of estrogen receptor in gastric cancer using immunohistochemical staining of monoclonal antibody. Cancer 1991; 67: 2401-6.

6 Masiakowski P, Breathnach R, Bloch J, Gannon F, Krust A Chambon $P$. Cloning of $\mathrm{cDNA}$ sequences of hormone regulated genes from the MCF-7 human breast cancer regulated genes from the MCF-7 human breast

7 Edwards DP, Adams DJ, McGuire WL. Estradiol stimulates synthesis of a major intracellular protein in a human breast cancer cell

8 Rio MC, Bellocq JP, Gairard B, Rasmussen UB, Krust A, Koehl C, et al. Specific expression of the pS2 gene in subclasses of breast cancers in comparison with expression of the estrogen and progesterone receptors and the oncogene ERBB2. Proc Natl Acad Sci USA 1987; 84 9243-7.

9 Cano A, Coffer AI, Adatia R, Millis R, Rubens RD, King RHB. Histochemical studies with an estrogen receptor related protein in human breast tumors. Cancer Res 1986; 46: 6475-80.
10 Chomczynski P, Sacchi N. Single step method of RNA isolation by guanidinium thiocyanate phenol-chloroform extraction. Anal Biochem 1987; 162: 156-9.

1 Green S, Walter P, Kumar V, Krust A, Bornert JM, Argos P, Chambon $P$. Human oestrogen receptor cDNA: sequence, expression and homology to v-erb-A. Nature 1986; 320: 134-9.

12 Mendelsohn ME, Zhu Y, O'Neil S. The 29-KDa proteins phosphorylated in thrombin-activated human platelets are forms of the estrogen receptor related 27-Kplatelets shock protein. Proc Natl Acad Sci USA 1991; 88: shock prot

13 Chan YL, Gutell R, Noller HF, Wool IG. The nucleotide sequence of a rat $18 \mathrm{~S}$ ribosomal ribonucleic acid gene and a proposal for the secondary structure of $18 \mathrm{~S}$ ribosomal ribonucleic acid. $\mathcal{F}$ Biol Chem 1984; 259: 224-30.

14 Bradford $M$. A rapid and sensitive method for the quantification of microgram quantities of protein utilizing the principle of protein-dye binding. Anal Biochem 1976; 72: 248-54.

15 Markopoulos C, Berger U, Wilson P, Gazet JC, Coombes RC. Oestrogen receptor content of normal breast cells and breast carcinomas throughout the menstrual cycle. $B M \mathcal{J}$ 1988; 296: 1349-51.

16 Coffer AI, Lewis KM, Brockas AJ, King RJB. Monoclonal antibodies against a component related to soluble antibodies against a component related to

17 Coffer AI, Spiller GH, Lewis KM, King RJB. Immunoradiometric studies with a monoclonal antibody against a component related to human estrogen receptor. Cancer Res 1985; 45: 3694-8.

18 Berry M, Nunez AM, Chambon P. Estrogen-responsive element of the human pS2 gene is an imperfectly palindromic sequence. Proc Natl Acad Sci USA 1989; 86: 1218-22.

19 Henry JA, Nicholson S, Hennessy C, Lennard TWJ, May FEB, Westley BR. Expression of the oestrogen regulated pNR-2 mRNA in human breast cancer: relation to oestrogen receptor mRNA levels and response to to oestrogen receptor mRNA levels and respon

20 Muller W, Borchard F. pS2 protein in gastric carcinoma and normal mucosa: association with clinicopathological parameters and patients survival. $f$ Pathol 1993; 171: 263-9.

21 Luqmani Y, Bennett C, Paterson I, Corbishley CM, Rio M, Chambon P, Ryall G. Expression of the pS2 gene in normal, benign and neoplastic human stomach. Int $f$ Cancer 1989; 44: 806-12.

22 Nunez AM, Berry M, Imler J, Chambon P. The 5' flanking region of the $\mathrm{pS} 2$ gene contains a complex enhancer region responsive to oestrogens, epidermal growth factor, region respone a tumour promoter (TPA), the c-H-ras on

$23 \mathrm{Kitaoka} H$. Sex hormone dependency and endocrine therapy for patients with diffuse carcinoma of the stomach. Fapanese fournal of Cancer Chemotherapy 1983; 10: 2453-60.

24 Kojima O, Takahashi T. Endocrine therapy for scirrhous carcinoma of the stomach. Fapanese fournal of Cancer Chemotherapy 1986; 13: 2526-31.

25 Harrison JD, Morris DL, Ellis IO, Jones JA, Jackson I. The effect of tamoxifen and estrogen receptor status on survival in gastric carcinoma. Cancer 1989; 64: 1007-10.

26 Harrison JD, Jones JA, Ellis IO, Morris DL. Oestrogen receptor D5 antibody is an independent negative progreceptor D5 antibody is an independent negative prog-
nostic factor in gastric cancer. Brf Surg 1991; 78: 334-6.

27 Tonnesen H, Bulow S, Fischerman K, Hjortrup A Pederson VM, Svendsen LB, et al. Effect of cimetidine on survival after gastric cancer. Lancet 1988; ii: 990-92.

28 Kittas C, Xynos E, Neonakis E, Fountos A, Aroni K Kittas C, Xynos E, Neonakis E, Fountos A, Aroni K,
Vassilakis JS. Sex related differences in serum gastrin concentrations and G- and D-cell populations of the gastric mucosa in guinea-pigs (experimental RIA and immunocytochemical study). Br $\mathcal{F}$ Exp Pathol 1986; 67: 229-33.

29 Lichtenberger LM, Nance DM, Gorski RA. Sex-related difference in antral and serum gastrin levels in the rat. Proc Soc Exp Biol Med 1976; 151: 785-8.

30 Truelove SC. Stilboestrol, phenobarbitone, and diet in chronic duodenal ulcer. BMF 1960; ii: 559-66. 